\title{
Addition of Fish Protein Hydrolysate for Enhanced Water Retention in Sous Vide Processing of Salmon
}

\author{
JP Ibarra' ${ }^{1}$ A Teixeira², R Simpson ${ }^{1,3}$, P Valencia1, M Pinto ${ }^{1}$ and S Almonacid ${ }^{1,3 *}$
}

${ }^{1}$ Department of Chemical and Environmental Engineering, Universidad Técnica Federico Santa María, P.O. Box 110-V, Valparaíso, Chile

${ }^{2}$ Agricultural and Biological Engineering Department, University of Florida, P.O Box 32611-0570, Gainesville, FL, USA

${ }^{3}$ Centro regional de Estudios en Alimentos Saludables (CREAS) Conicyt, Valparaíso, Regional Gore Valparaiso (R06I1004), Chile

\begin{abstract}
Scientific evidence has shown that high sodium consumption from salt can lead to arterial hypertension. Most salt is consumed through processed food to enhance flavor or to increase water retention in the case of processed meats and seafood. In the processing of fish, such as salmon, considerable organic waste is generated that could be reused in the form of a protein hydrolysate if it could serve a useful purpose. The hypothesis of the work presented in this paper was that protein hydrolysate made from salmon waste could replace salt for the purpose of enhancing water retention in the (Sous Vide) processing of salmon filets. The main objective of this research was to observe the effect of different combinations of protein hydrolysate and salt concentration on the drained weight of the final product, and to determine that the results obtained were statistically and economically significant. Response surface methodology was used to study the simultaneous effects of different combinations of protein hydrolysate and salt concentrations on resulting drained weight. A $4 \times 4$ factorial design was used, where concentrations of protein hydrolysate were $0 \%, 7 \%, 10 \%$ and $14 \%$, while salt concentrations were those established by the U.S. Department of Agricultural for salmon as regular, low, very low and no added sodium $(1.9 \%, 0.6 \%, 0.2 \%$ and $0 \%$, respectively). Results showed that the combination of $14 \%$ hydrolysate and $0.2 \%$ salt achieved nearly the same level of water retention as the standard industry practice of adding nearly $2 \%$ salt. This could mean that processors could reduce current levels of salt addition by $90 \%$ without compromising process performance, nor color or texture in the final product.
\end{abstract}

Keywords: Salmon; Sous vide; Water retention; Salt addition; Protein hydrolysate; Process yield

\section{Introduction}

World population continues to increase bringing with it an increasing demand for processed foods, and associated amounts of organic waste being generated. Approximately $50 \%$ of raw material processed in the food industry is discarded as organic waste with the associated cost of waste disposal and adverse effects on the environment [1]. At the same time, our society is preoccupied with the need to combat chronic health issues, such as hypertension, diabetes, cardiovascular disease, and various types of cancer. These health problems are among the principal causes of death in the world, and were responsible for $63 \%$ of deaths with $29 \%$ being persons less than 60 years of age [2]. Changes in diet and life style are among the most effective means for combating these chronic diseases. As such, increasing attention is being given to incorporating additives in processed foods that act as bioactive ingredients in helping to prevent these chronic diseases [3]. By-products from the food industry have the potential for being used as bioactive ingredients or additives in processed foods that can make them "functional foods", increasing their value and fostering a more positive image of the food industry. A functional food is defined by the International Food Information Council (IFIC) as a product containing a specific intentionally added substance for the purpose of improving its effect on promoting good health and well-being.

A common practice in the food industry is the addition of salt to thermally processed meat and fish products to prevent weight loss that would otherwise occur because of reduced water holding capacity caused by the heat treatment. In the majority of developed countries the greatest contributor to salt intake is the salt added to processed foods, which is out of the consumer's control. This should encourage the food industry to produce new functional foods with lower salt content, putting just as much emphasis on ingredient formulation as on process development, including utilization of by-products. In this regard, the Chilean salmon industry is an interesting candidate for the application of such new processing technologies.

Chile is the second largest producer of salmon in the world, reaching nearly 300,000 tons in the year 2010 , representing $23 \%$ of world production [4]. Approximately $45 \%$ of Chilean salmon is exported as frozen filets or held fresh under refrigeration, while only $18 \%$ is further processed for export as smoked, salted or canned [5]. The waste byproduct from these processing operations amounts to $47 \%$ of the fish processed, and consists largely of fish heads, viscera, bones, scales, fins, peel and cartilage [6]. These by-products contain large quantities of proteinaceous material, and are often processed into fish meal, flour and oil, which are products of lower commercial value. Another alternative for utilization of these by-products is the manufacture of fish protein hydrolysate. Various studies have demonstrated that enzymatically hydrolyzed proteins from salmon muscle contain peptides with bioactive properties that act as antioxidants and antihypertensive, among others. They also possess desirable functional properties such as enhanced solubility and water holding capacity [7-9]. Other studies

*Corresponding author: Sergio Almonacid, Department of Chemical and Environmental Engineering, Universidad Técnica Federico Santa María, P.O. Box 110-V, Valparaíso, Chile, E-mail: Sergio.almonacid@usm.cl

Received March 19, 2013; Accepted May 21, 2013; Published May 30, 2013

Citation: Ibarra JP, Teixeira A, Simpson R, Valencia P, Pinto M, et al. (2013) Addition of Fish Protein Hydrolysate for Enhanced Water Retention in Sous Vide Processing of Salmon . J Food Process Technol 4: 241. doi:10.4172/21577110.1000241

Copyright: ( 2013 Ibarra JP, et al. This is an open-access article distributed under the terms of the Creative Commons Attribution License, which permits unrestricted use, distribution, and reproduction in any medium, provided the original author and source are credited. 
have been reported on the application of protein hydrolysates for use as functional ingredients in foods [10-12].

Among thermal processes used in the food industry, the process for making "Sous Vide" products appears as an interesting alternative for producing salmon filets "ready to serve", and would help supply the increasing consumer demand for these types of products [13], while offering processed salmon products with greater market value. Sous Vide processing involves application of a controlled cooking-pasteurization heat treatment to a raw food that is vacuum packaged in a heat-stable pouch or package. After this heat treatment, the product is rapidly cooled to temperatures around $0-3^{\circ} \mathrm{C}$, and stored under refrigeration for up to five weeks before reheating and serving. Advantages of this treatment are greater convenience and improved sensory quality and nutrition retention over traditional thermally processed products [14]. One of the principal disadvantages is the appearance of undesirable "drip loss" within the package (water exuded from the product because of loss of water retention during the heat treatment).

The hypothesis of the work presented in this paper was that protein hydrolysate made from salmon waste could replace all or part of added salt for the purpose of enhancing water retention in thermal processes used in the Sous Vide processing of salmon filets, and without compromising color or texture in the final product. Therefore, the principal objective of this work was to determine the effect of different combinations of protein hydrolysate and salt concentration on the drained weight of final product after thermal processing without compromising color or texture, and to determine if the results obtained were statistically and economically significant.

\section{Materials and Methods}

\section{Preparation of protein hydrolysate}

The procedure utilized for producing the protein hydrolysate was based on the methodology reported by Castillo [15]. Frozen salmon muscle tissue (discards) were procured from a local salmon processing plant and kept frozen at $-20^{\circ} \mathrm{C}$ until they were thawed at room temperature overnight prior to undergoing hydrolysis the next day. Food grade Alcalase 2.4L enzyme (Novozymes, Bagsvaerd, Denmarkwas) selected for its ability to produce hydrolysates with specific functional properties, and because it is widely used in the hydrolysis of fish muscle $[7,8,16,17]$. Enzymatic hydrolysis was performed in a stirred batch reactor (1.5L glass beaker). Temperature was held constant at $40^{\circ} \mathrm{C}$, while $\mathrm{pH}$ was adjusted to 7.5 with $\mathrm{NaOH} 1 \mathrm{~N}$ in accordance with Kristinsson and Rasco [17]

The specification of all reactants used in the protein hydrolysis are shown in table 1.

The Degree of Hydrolysis (DH) was monitored as the final processing criteria in accordance with Kristinsson and Rasco [17]. These authors analyzed different functional properties of salmon protein hydrolysates obtained from several alkaline proteases, including Alcalase 2, 4 L. Water Holding Capacity (WHC) obtained for hydrolysates with 5 and $10 \% \mathrm{DH}$, was not significantly different, bit the hydrolysis time required to obtain $5 \% \mathrm{DH}$ increases 4 to 5 fold to achieve $10 \% \mathrm{DH}$. Accordingly, $5 \% \mathrm{DH}$ was used to generate the hydrolysate to be used as additive in Sous Vide salmon processing. Characterization of the hydrolysate obtained after $5 \% \mathrm{DH}$, is made by determining its alpha-amino groups $\left(-\mathrm{NH}_{2}\right)$ through the OPA method as shown by Nilssen et al. [18] (Figures 1 and 2).

\section{Design of experiments}

Response surface methodology was used to study the simultaneous effects of different combinations of protein hydrolysate and salt concentrations on resulting drained weight. A $4 \times 4$ factorial design was used, where concentrations of protein hydrolysate selected were $0 \%, 7 \%, 10 \%$ and $14 \%$, while salt concentrations were those found for canned salmon in the Commercial Item Description (CID) established by the U.S. Department of Agriculture (USDA) for salmon as regular, low, very low and no added sodium, with nominal concentrations of $1.9 \%, 0.6 \%, 0.2 \%$ and $0 \%$, respectively. To add the salt into the muscle tissue, the amount of salt needed is weighted and then dissolved in $0.7 \mathrm{~mL}$ of distilled water and finally injected in the respective salmon sample. Precise concentrations of salt and their corresponding sodium content are given in table 2.

The levels chosen for added protein hydrolysate $(0,7,10$ and $14 \%)$ were those used by Szerman et al. [19], in their study with whey protein concentrate as an additive in vacuum-packed meat products for the

\begin{tabular}{|l|c|}
\hline Total Mass & $1000 \mathrm{~g}$ \\
\hline Protein mass & $55 \mathrm{~g}$ \\
\hline \%Protein (sustrate) in hydrolysis solution & $5 \%$ \\
\hline Salmón muscle & $369 \mathrm{~g}$ \\
\hline Water volume & $720 \mathrm{~mL}$ \\
\hline Enzyme volume & $928 \mu \mathrm{L}$ \\
\hline Enzymatic volume solution & $10 \mathrm{~mL}$ \\
\hline$\%$ Salmon muscle protein & $16.4 \%$ \\
\hline
\end{tabular}

Table 1: Hydrolysis reactants.

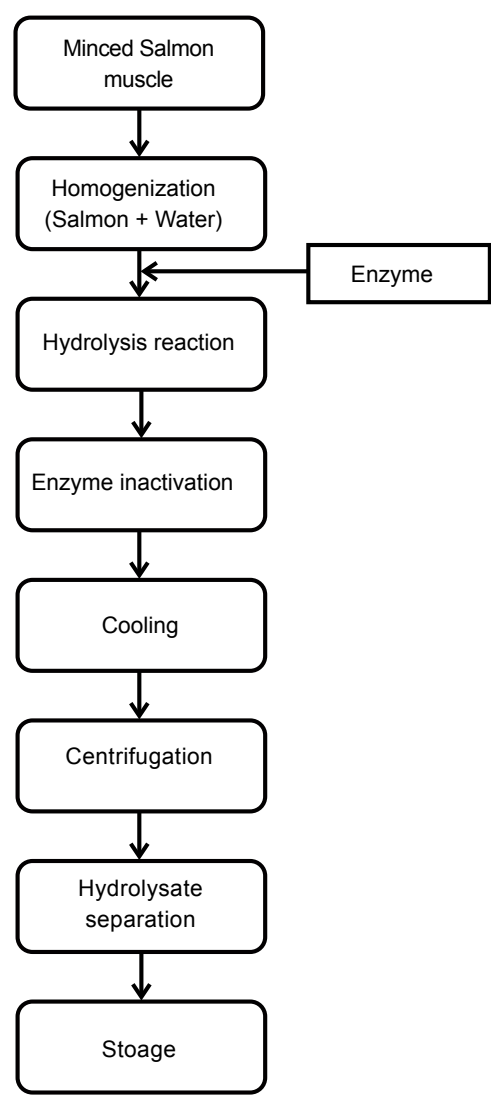

Figure 1: Schematic diagram of process steps taken to obtain protein hydrolysate. 
Citation: Ibarra JP, Teixeira A, Simpson R, Valencia P, Pinto M, et al. (2013) Addition of Fish Protein Hydrolysate for Enhanced Water Retention in Sous Vide Processing of Salmon . J Food Process Technol 4: 241. doi:10.4172/2157-7110.1000241

purpose of enhancing water retention. The four levels of salt and fish protein hydrolysate concentrations used in the design of experiments are summarized in table 3 .

The experimental design consisted of two control variables with four levels for each variable that translated into the $4 \times 4$ factorial design of experiments detailed in table 4 .

\section{Determination of water holding capacity (WHC)}

Water-holding capacity (WHC) is the capacity of muscle tissue to resist the loss of water. It is equally important with respect to commercial productivity as it is to consumer acceptance in the market place. The method used for measuring WHC in this study was taken from that reported by Almonacid et al. [20], in which a sample of muscle tissue is subjected to high-speed centrifugation as the driving force to mechanically expel water held within the sample. Specially designed 2-part centrifuge tubes were developed for this purpose, consisting of a larger outer tube partially filled with glass beads to create a porous bed through which the expelled water could flow. The bed of glass beads was topped with a smaller concentric glass tube (sample holder) fitted with a porous polyester membrane at the base covered with a paper filter upon which the sample of muscle tissue was placed (Figure 3).

The water-holding capacity (WHC) can be expressed as the

\begin{tabular}{|c|c|c|}
\hline Level & Quantity of Na & (\%NaCl) \\
\hline Regular & $750 \mathrm{mg} \mathrm{Na} / 100 \mathrm{~g}$ & 1.875 \\
\hline Low & $140 \mathrm{mg}$ per portion & 0.625 \\
\hline Very low & $35 \mathrm{mg}$ per portion & 0.156 \\
\hline No salt added & $\begin{array}{c}\text { No sodium added during } \\
\text { processing }\end{array}$ & $\begin{array}{c}\text { No sodium added during } \\
\text { processing }\end{array}$ \\
\hline
\end{tabular}

Table 2: Levels of sodium content $(\mathrm{Na})$ and their equivalent in added salt $(\mathrm{NaCl})$ established by the U.S. Department of Agriculture (USDA) for salmon.

\begin{tabular}{|c|c|c|}
\hline & \multicolumn{2}{|c|}{ Variables } \\
\hline & $\% \mathrm{NaCl}(\mathbf{p} / \mathbf{p})$ & $\% \mathrm{FPH}(\mathbf{p} / \mathbf{p})$ \\
\hline $\mathbf{L}$ & $\mathrm{X} 1$ & $\mathrm{X} 2$ \\
\hline $\mathbf{2}$ & 0 & 0 \\
\hline $\mathbf{3}$ & 0.2 & 7 \\
\hline $\mathbf{4}$ & 0.6 & 10 \\
\hline
\end{tabular}

Table 3: Levels of salt $(\mathrm{NaCl})$ and fish protein hydrolysate $(\mathrm{FPH})$ used as control variables in the design of experiments.

\begin{tabular}{|c|c|c|c|}
\hline Group & Treatment & $\% \mathrm{NaCl}$ & $\% \mathrm{FPH}$ \\
\hline \multirow{4}{*}{ I } & 1 & 0 & 0 \\
\hline & 2 & 0 & 7 \\
\hline & 3 & 0 & 10 \\
\hline & 4 & 0 & 14 \\
\hline \multirow{4}{*}{ II } & 5 & 0.2 & 0 \\
\hline & 6 & 0.2 & 7 \\
\hline & 7 & 0.2 & 10 \\
\hline & 8 & 0.2 & 14 \\
\hline \multirow{4}{*}{ III } & 9 & 0.6 & 0 \\
\hline & 10 & 0.6 & 7 \\
\hline & 11 & 0.6 & 10 \\
\hline & 12 & 0.6 & 14 \\
\hline \multirow{4}{*}{ IV } & 13 & 1.9 & 0 \\
\hline & 14 & 1.9 & 7 \\
\hline & 15 & 1.9 & 10 \\
\hline & 16 & 1.9 & 14 \\
\hline
\end{tabular}

Table 4: Factorial design of experiments for response surface methodology.

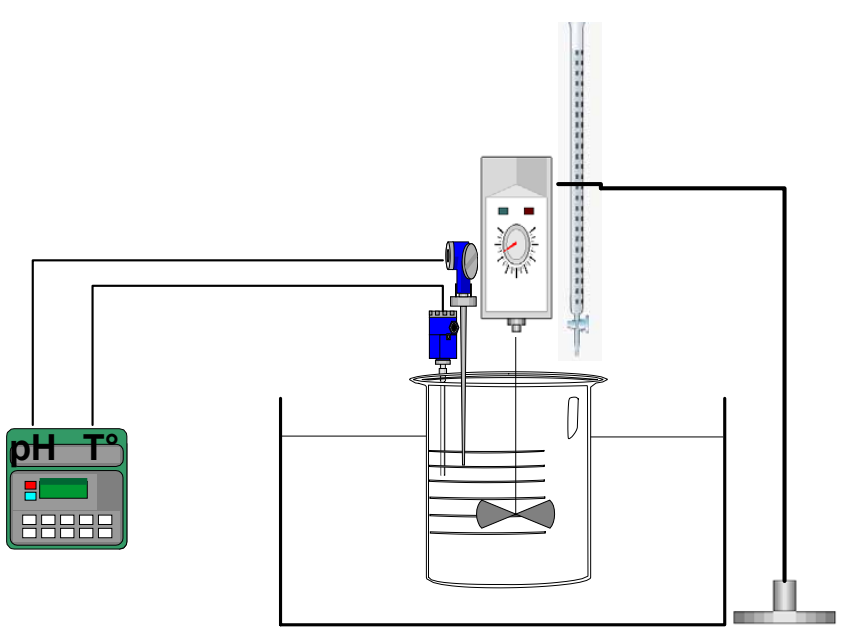

Figure 2: Schematic illustration of laboratory setup for enzyme hydrolysis.
A

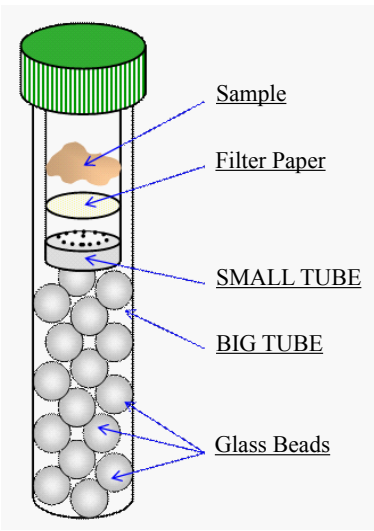

B

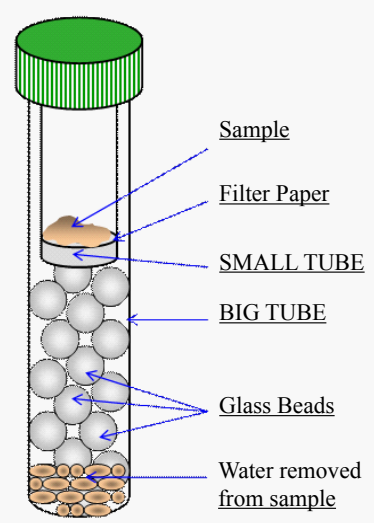

Figure 3: Centrifuge tubes used for determination of water holding capacity, showing sample prior to centrifugation (a) and after centrifugation (b).

percentage of water retained per 100 grams of water present in the sample prior to centrifugation, as indicated by equation 1 .

$$
\begin{aligned}
& W H C=\frac{W r}{W i} \times 100 \\
& W r=M c-M d \\
& W i=W r+W e
\end{aligned}
$$

where $W i$ : Weight of water present prior to centrifugation (g), Wr: Weight of water retained in the sample after centrifugation (g), We: Weight of water removed from the sample during centrifugation $(\mathrm{g})$, $M c$ : Weight of centrifuged sample (g), Md: Dry weight of sample (g).

\section{Experimental procedure}

Samples of salmon were taken from the thickest part of whole filets and cut into $4 \mathrm{~cm}$-squares of $0.5 \mathrm{~cm}$ thickness. Samples were weighed prior to vacuum sealing in retortable pouches for precooking in a hot water bath at $70^{\circ} \mathrm{C}$ for 5 minutes. Then, immediately quenched in a cold water bath for cooling to approximately $18^{\circ} \mathrm{C}$. The cool precooked filets were removed from the pouches, and cleaned of connective tissue 
(released during the precook treatment) prior to being weighed once again to determine weight loss caused by precooking. They were then ready for repackaging in new pouches with added salt and/or protein hydrolysate according to the design of experiments.

A micropipette was used to transfer the required amount of fish protein hydrolysate to a small Petri dish, drawn from the Petri dish into a syringe, and injected into the sample at distinct locations around the surface of the filet. To accomplish the salt addition, the required amount of salt was placed in a Petri dish and dissolved in $0.7 \mathrm{ml}$ distilled water. Then, the aqueous salt solution was drawn from the Petri dish into a syringe, and injected into the sample at distinct locations around the surface of the filet. For those samples requiring a mixture of salt and hydrolysate, the required amounts of each were mixed together in one Petri dish until all the salt had dissolved; then injected into the sample filet by syringe as before. The injected samples were then vacuum sealed in their new pouches, and refrigerated overnight at $2^{\circ} \mathrm{C}$ to allow diffusion for achieving a uniform distribution of salt and hydrolysate throughout the salmon tissue. The next day, the vacuumsealed pouched samples were subjected to the Sous Vide heat treatment process.

The thermal-pasteurization time, evaluated at the muscle slowest heating point, was that to achieve $6 \mathrm{D}$ Log reduction of Listeria monocytogenes according to Nyati et al. [21]. The resulting process was $20 \mathrm{~min}$ in a hot water bath at $70^{\circ} \mathrm{C}$, followed by a cooling step to $18^{\circ} \mathrm{C}$ in a cold water bath, and finally the processed product was placed under refrigerated storage at $2^{\circ} \mathrm{C}$ for three days to reach osmotic equilibrium between the additives and the salmon muscle tissue. At this point the filets were taken from their pouches for determination of drained weight, color and texture.

\section{Measurement of color and texture}

Color measurements were made with CR- 400 colorimeter (Chroma Meter; Konica Minolta Sensing Inc. Osaka, Japan) using the $L^{*}, a^{*}$, $b^{\star}$ system of color parameters. Color on the surface of salmon filets varies substantially from zone to zone on the surface. Therefore, color measurements were taken at the same location point before and after heat treatment to be sure any color differences observed were caused by the heat treatment alone, and not because of differences in location of measurement. The average of three readings from the colorimeter was taken as the result of one measurement, and measurements were taken in triplicate on the central point of each sample filet.

Texture measurements were made on a Texture measurements were made on a Texture Analyzer CT3 (Brookfield, Middleboro, MA, USA) under operating conditions specified in table 5. Compression tests were carried out to measure the force required to achieve $30 \%$ deformation. This would correlate to a measurement of rigidity (force/deformation) at a specified degree of deformation. It would be perceived as "firmness" by the consumer, referred to as "firmness" in this and study [22].

\section{Statistical analysis}

Response variables: Response variables from the heat treatment experiments were analyzed by the method of Response Surface Methodology (RSM) using MINITAB $15^{\circ}$ software (State College, USA), which performed a complete statistical analysis of all the data. Results obtained from executing the $4 \mathrm{x} 4$ factorial designs were entered into the MINITAB program, and analyzed through RSM to recognize how the response variables can vary as a function of variations in the control variables.
Color and texture: In order to recognize any effects from different combinations of salt and FPH on color and texture, and whether or not any differences would be statistically significant, results from color and texture measurements were analyzed using the statistical procedure called Analysis of Variance (ANOVA) with the help of SPSS Statistics 17.0 commercially available software (SPSS: Statistical Package for Social Sciences, IBM Corporation, New York, United States).

\section{Results and Discussion}

The concentration of $-\mathrm{NH}_{2}$ in the $5 \% \mathrm{DH}$ (and $5 \%$ protein initial concentration) hydrolysate was found to be $0.075 \mathrm{M}$. This was the hydrolysate used for injection in all respective experiments.

\section{Process response variables}

Response variables from the pre-cook and Sous Vide heat treatments consisted of:

- Weight loss from pre-cook heat treatment (\%P1)

- Weight loss from the Sous Vide heat treatment (\%P2)

- Total weight loss from both treatments combined (\%PT)

Results obtained for these three parameters as a function of the various additive combinations used in the design of experiments are summarized in table 6 .

Weight loss as a result of pre-cooking $(\% \mathrm{P} 1)$ was essentially the same for all samples at approximately $12 \%$. No differences were expected since all samples were subjected to the very same thermal process conditions of pre-cooking, and contained no additives. In contrast, total weight loss (\%PT) varied from nearly $16 \%$ to as much as $24 \%$ as a function of the various additive combinations used in the design of experiments. Results of particular interest are presented graphically in figure $4(\mathrm{a}-\mathrm{d})$. Figure $4(\mathrm{a})$ shows the effect of salt addition alone on

\begin{tabular}{|c|c|}
\hline Parameter & Value \\
\hline Carge & $25000 \mathrm{~g}$ \\
\hline Velocity Prove & $1 \mathrm{~mm} / \mathrm{s}$ \\
\hline Activation carge & $10 \mathrm{~N}$ \\
\hline$\%$ Deformation & 30 \\
\hline Prove & TA 10 \\
\hline
\end{tabular}

Table 5: Operating conditions used with Brookfield Texture Analyzer.

\begin{tabular}{|c|c|c|c|c|c|c|}
\hline Group & Treatment & $\% \mathrm{NaCl}$ & $\% \mathrm{FPH}$ & \%P1* & \%P2* & $\% \mathrm{PT}^{*}$ \\
\hline \multirow{4}{*}{ I } & 1 & 0 & 0 & 12.04 & 11.93 & 23.93 \\
\hline & 2 & 0 & 7 & 11.80 & 10.63 & 22.63 \\
\hline & 3 & 0 & 10 & 11.90 & 9.49 & 21.49 \\
\hline & 4 & 0 & 14 & 11.83 & 6.73 & 18.73 \\
\hline \multirow{4}{*}{ II } & 5 & 0.2 & 0 & 12.10 & 8.99 & 20.99 \\
\hline & 6 & 0.2 & 7 & 12.20 & 7.64 & 19.64 \\
\hline & 7 & 0.2 & 10 & 12.05 & 7.27 & 19.27 \\
\hline & 8 & 0.2 & 14 & 12.02 & 5.93 & 17.93 \\
\hline \multirow{4}{*}{ III } & 9 & 0.6 & 0 & 11.90 & 8.30 & 20.30 \\
\hline & 10 & 0.6 & 7 & 11.95 & 7.81 & 19.81 \\
\hline & 11 & 0.6 & 10 & 12.23 & 7.47 & 19.47 \\
\hline & 12 & 0.6 & 14 & 12.02 & 5.49 & 17.49 \\
\hline \multirow{4}{*}{ IV } & 13 & 1.9 & 0 & 11.80 & 4.86 & 16.86 \\
\hline & 14 & 1.9 & 7 & 12.20 & 4.77 & 16.77 \\
\hline & 15 & 1.9 & 10 & 12.00 & 4.49 & 16.49 \\
\hline & 16 & 1.9 & 14 & 12.05 & 4.14 & 16.14 \\
\hline
\end{tabular}

Table 6: Results for process response variables obtained from the various additive combinations used in executing the design of experiments. 
Citation: Ibarra JP, Teixeira A, Simpson R, Valencia P, Pinto M, et al. (2013) Addition of Fish Protein Hydrolysate for Enhanced Water Retention in Sous Vide Processing of Salmon . J Food Process Technol 4: 241. doi:10.4172/2157-7110.1000241

Page 5 of 7

total weight loss, and reveals the degree to which weight loss diminishes as salt concentration increases from 0 to $1.9 \%$. Conversely, figure 4 (b) shows the effect of fish protein hydrolysate (FPH) addition alone on total weight loss, and reveals the degree to which weight loss diminishes as FPH concentration increases from 0 to $14 \%$. Note that the minimum weight loss achieved by FPH alone (18.7\%) is remarkably close to that of salt alone (16.8\%). These findings confirm the effectiveness of adding fish protein hydrolysate for purposes of minimizing weight loss.

The effects of adding combinations of salt and FPH together for $7 \%$ and $14 \% \mathrm{FPH}$ are shown in figures $4(\mathrm{c})$ and 4(d), respectively. Figure 4(d) for the case of $14 \%$ FPH shows that less than $18 \%$ weight loss can be achieved with only one tenth the amount of salt addition normally used in current practice ( 0.2 vs. $1.9 \%)$.

Figure 5 illustrates the significance of these findings by comparing total weight loss achieved from the combination of $14 \% \mathrm{FPH}$ and $0.2 \%$ salt (17.9\%) with that achieved from the control (Regular) containing nearly $2 \%$ salt addition (16.9\%). By adding $14 \%$ fish protein hydrolysate made from salmon by-products (a natural protein ingredient), salt addition can be reduced by $90 \%$ at the small price of accepting just one percent less weight loss.
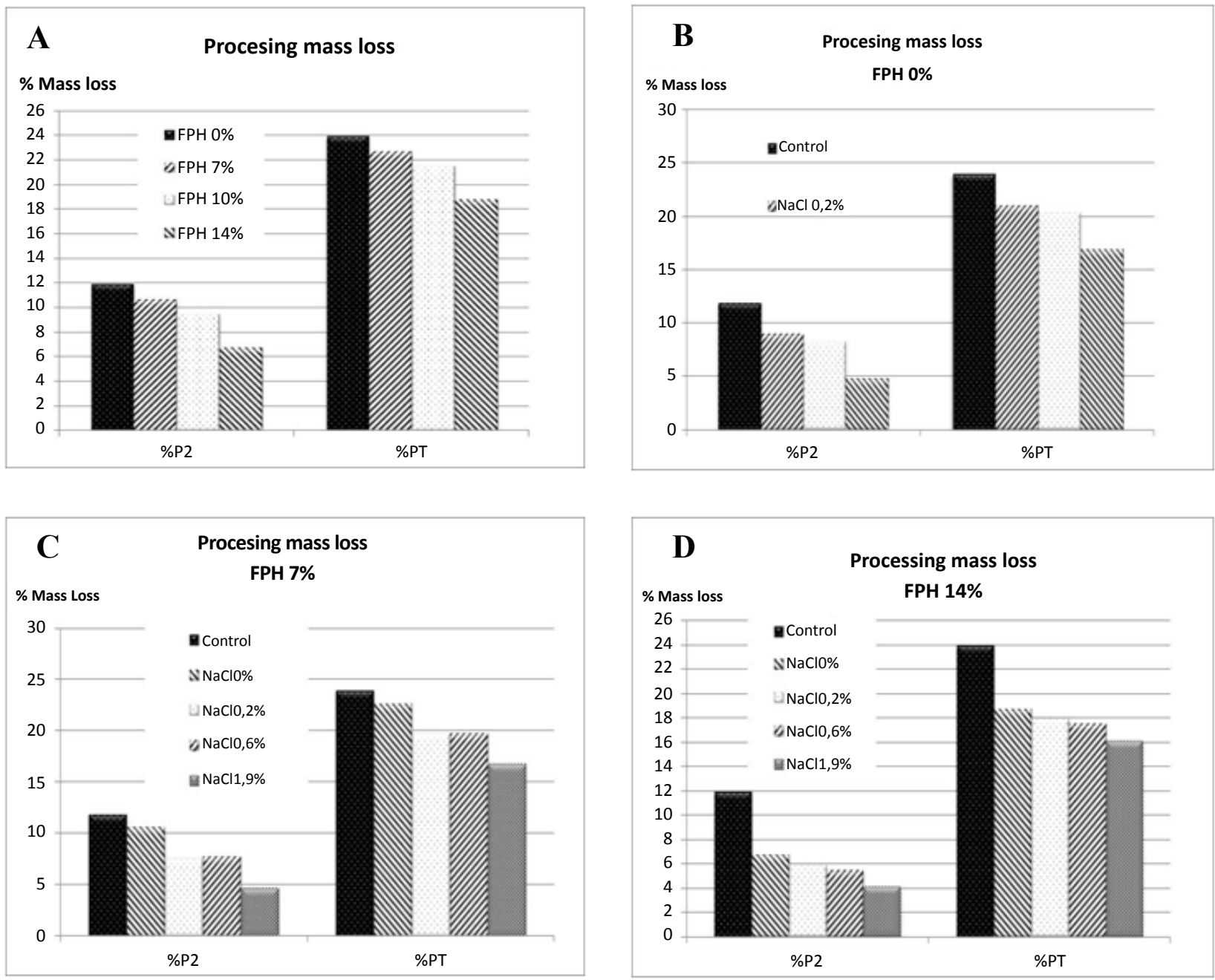

Figure 4: Effect of salt $(\mathrm{NaCl})$ and fish protein hydrolysate $(\mathrm{FPH})$ addition on total weight loss in salmon filets from Sous Vide process heat treatments in response to adding salt alone (a), FPH alone (b), salt with $7 \% \mathrm{FPH}(\mathrm{c})$, and salt with $14 \% \mathrm{FPH}(\mathrm{d})$.

\section{Color measurments}

Color changes affected by the heat treatments and additive combinations are summarized in table 7 , in which mean values and standard error are presented for each color parameter $(\Delta \mathrm{L}, \Delta \mathrm{a}, \Delta \mathrm{b})$. Values followed by different letters in the same column indicate significant differences. The $\Delta \mathrm{L}$ parameter (brightness) was unaffected. However significant changes were found in the $\Delta \mathrm{a}$ (red) and $\Delta \mathrm{b}$ (yellow) parameters, but only between samples with and without additives. Both these parameters were intensified by the addition of either salt alone, FPH alone, or combinations of both. These color changes were likely the result of myoglobin denaturation and oxidation of carotenoid pigments. The increased intensity of the red and yellow color tones are desirable attributes with respect to consumer acceptance, and are achieved equally by addition of either salt alone, FPH alone, or combinations of both.

\section{Texture measurement}

Results from texture measurements on salmon filets processed with the various additive combinations are summarized in figure 6. Measurements are reported as "firmness", defined as the force (Newtons) required to achieve a 30\% deformation under compression

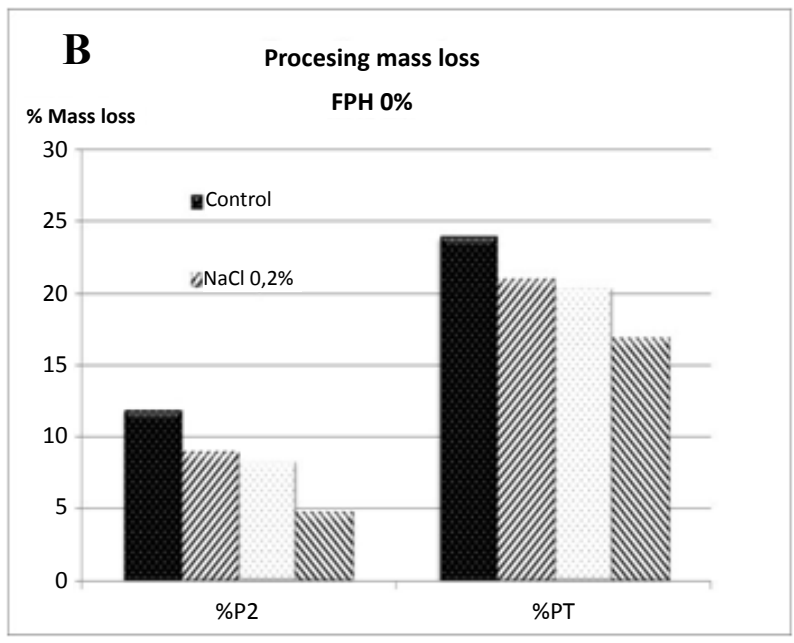




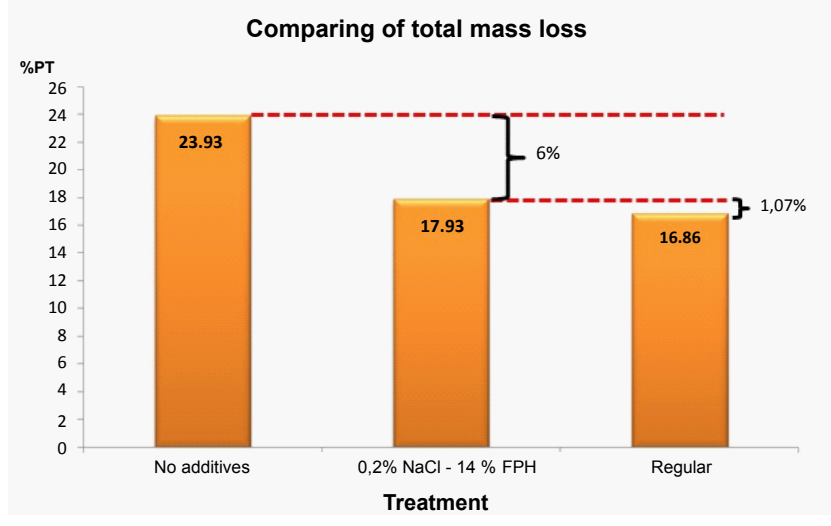

Figure 5: Comparison of total weight loss in salmon filets from Sous Vide processing resulting from the use of no additives, combination of $14 \% \mathrm{FPH}$ and $0.2 \%$ salt, and with $2 \%$ salt addition alone (control)

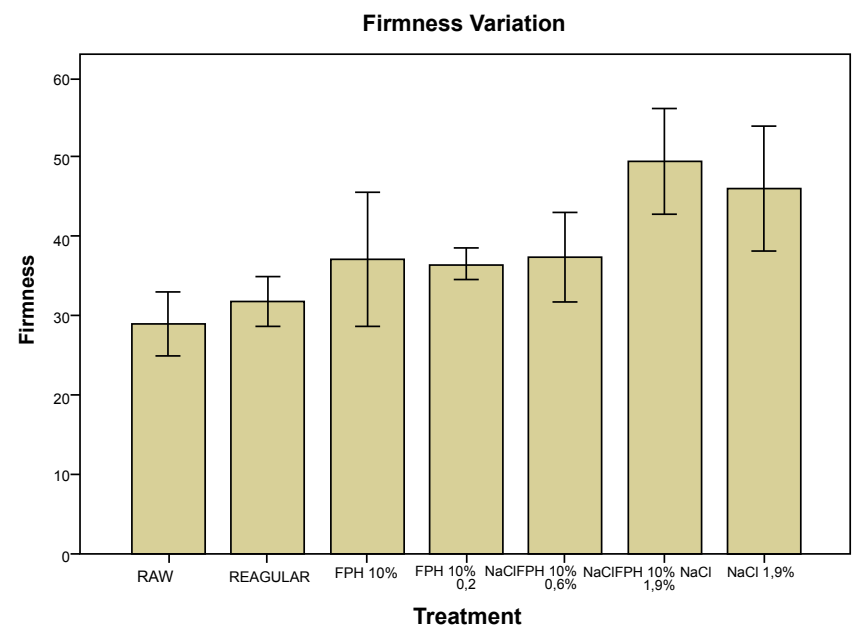

Figure 6: Effect of $\mathrm{NaCl}$ and FPH on "firmness" (Newtons force per $30 \%$ deformation) of Sous Vide salmon filets.

\begin{tabular}{|c|c|c|c|c|c|}
\hline & & & $\Delta L^{*}$ & $\Delta \mathbf{a}^{*}$ & $\Delta \mathbf{b}^{*}$ \\
\hline \multicolumn{6}{|l|}{$\mathrm{NaCl}$} \\
\hline $0 \%$ & & & $25.9 \pm 1.6$ & $-1.8 \pm 0.7 a$ & $1.0 \pm 0.5 \mathrm{a}$ \\
\hline \multirow[t]{2}{*}{$1.9 \%$} & & & $26.7 \pm 1.0$ & $0.7 \pm 0.1 b$ & $3.6 \pm 0.3 b$ \\
\hline & & $p$-Value & 0.691 & 0.011 & 0.001 \\
\hline \multicolumn{6}{|l|}{ FPH } \\
\hline $0 \%$ & & & $25.9 \pm 1.6$ & $-1.8 \pm 0.7 \mathrm{a}$ & $1.0 \pm 0.5 \mathrm{a}$ \\
\hline $10 \%$ & & & $28.2 \pm 1.1$ & $2.6 \pm 0.5 b$ & $5.5 \pm 0.7 b$ \\
\hline \multirow[t]{2}{*}{$14 \%$} & & & $27.7 \pm 1.4$ & $1.8 \pm 0.2 b$ & $5.3 \pm 0.6 b$ \\
\hline & & $p$-Value & 0.478 & 0.0001 & 0.0001 \\
\hline \multicolumn{6}{|l|}{ FPH $\times$ NaCl } \\
\hline $0 \% \mathrm{NaCl}$ & $0 \% \mathrm{FPH}$ & & $25.9 \pm 1.6$ & $-1.8 \pm 0.7 a$ & $1.0 \pm 0.5 a$ \\
\hline $0 \% \mathrm{NaCl}$ & $10 \% \mathrm{FPH}$ & & $28.1 \pm 1.1$ & $2.6 \pm 0.5 \mathrm{c}$ & $5.5 \pm 0.7 b, c$ \\
\hline $0.2 \% \mathrm{NaCl}$ & $10 \% \mathrm{FPH}$ & & $29.8 \pm 1.7$ & $3.7 \pm 0.4 \mathrm{c}$ & $6.9 \pm 0.5 c$ \\
\hline $0.6 \% \mathrm{NaCl}$ & $10 \% \mathrm{FPH}$ & & $27.8 \pm 1.0$ & $2.4 \pm 0.2 b, c$ & $4.8 \pm 0.4 b, c$ \\
\hline $1.9 \% \mathrm{NaCl}$ & $0 \% \mathrm{FPH}$ & & $26.7 \pm 1.0$ & $0.7 \pm 0.1 \mathrm{~b}$ & $3.6 \pm 0.3 b$ \\
\hline \multirow[t]{2}{*}{$1.9 \% \mathrm{NaCl}$} & $10 \% \mathrm{FPH}$ & & $26.4 \pm 1.4$ & $2.7 \pm 0.4 \mathrm{c}$ & $3.8 \pm 0.6 b$ \\
\hline & & $p$-Value & 0.356 & 0.0001 & 0.0001 \\
\hline
\end{tabular}

Table 7: Effects of $\mathrm{NaCl}$ and $\mathrm{FPH}$ addition on color of salmon filets. testing with a Brookfield texturometer. Addition of either salt alone, FPH alone, or combinations of both increased firmness. This means that samples contain additives had greater firmness, which is another desirable attribute for greater consumer acceptance. This increase in firmness was likely a reflection of greater cellular turger pressure achieved by the increased water holding capacity attributed to the addition of salt and/or hydrolysate.

\section{Conclusions}

Results from this study suggest the following conclusions:

- Addition of fish protein hydrolysate (FPH) into the muscle tissue of salmon filets undergoing Sous Vide processing will significantly improve drained weight when compared with filets processed without additives, and confirms the hypothesis put forward at the beginning of the study.

- Specifically, the addition of $14 \% \mathrm{FPH}$ increases drained weight by five percentage points in comparison with no additives, and achieves nearly the same result as the common industry practice of $2 \%$ salt addition.

- Drained weight can be further improved when FPA and salt are used together as combined additives, allowing for lower and lower salt concentrations to achieve the same effect.

- Best results were obtained with a combination of $14 \%$ FPH and $0.2 \%$ salt, allowing normal salt addition in current industry practice to be be reduced by $90 \%$ at the small price of accepting just one percent less in drained weight.

- The addition of FPH alone or in combination with salt at the levels used in this study had no significant effect on color or texture when compared with control samples containing $1.9 \%$ salt used in current industry practice.

\section{Acknowledgements}

Author Sergio Almonacid is grateful for financial support provided by CONICYT through the FONDECYT project 1121147

Author Pedro Valencia is grateful for financial support provided by CONICYT through the FONDECYT project 11110249

\section{References}

1. Almonacid S, Simpson R, Teixeira AA (2009) Rethinking Food Waste Management and Utilization. Food Technology 63: 160.

2. OMS (2011) "Enfermedades Crónicas". Temas de Salud

3. OMS (2003) Diet, Nutrition and the Prevention of Chronic Diseases. OMS technical flies, $n^{\circ} 916$.

4. AQUA (2011) Un 2010 marcado por los altos precios. pp 30-37

5. Salmon Chile (2009) Evolución de las Exportaciones de Valor agregado.

6. Liaset B, Nortvedt R, Lied E, Espe M (2002) Studies on the nitrogen recovery in enzymic hydrolysis of Atlantic salmon (Salmo salar, $L$ ) frames by Protamex ${ }^{\mathrm{TM}}$ protease. Process Biochem 37: 1263-1269.

7. Kristinsson HG, Rasco BA (2000) Fish protein hydrolysates: production biochemical and functional properties. Crit Rev Food Sci Nutr 40: 43-81.

8. Gbogouri GA, Linder M, Fanni J, Parmentier M (2004) Influence of Hydrolysis Degree on the Functional Properties of Salmon Byproducts Hydrolysates. J Food Sci 69: C615-C622.

9. Guérard F, Decourcelle N, Sabourin C, Floch-Laizet C, Le Grel L, et al. (2010) Recent developments of marine ingredients for food and nutraceutical applications: a review. Le Journal des Sciences Halieutique et Aquatique 2: $21-27$ 
Citation: Ibarra JP, Teixeira A, Simpson R, Valencia P, Pinto M, et al. (2013) Addition of Fish Protein Hydrolysate for Enhanced Water Retention in Sous Vide Processing of Salmon . J Food Process Technol 4: 241. doi:10.4172/2157-7110.1000241

10. Bougatef A, Nedjar-Arroume N, Manni L, Ravallec R, Barkia A, et al. (2010) Purification and identification of novel antioxidant peptides from enzymatic hydrolysates of sardinelle (Sardinellaaurita) by-products proteins. Food Chem 118: 559-565.

11. Kim SK, Mendis E (2006) Bioactive compounds from marine processing byproducts - A review. Food Res Int 39: 383-393.

12. Shahidi F, Han XQ, Synowiecki J (1995) Production and characteristics of protein hydrolysates from capelin (Mallotus villosus). Food Chem 53: 285-293.

13. Resurreccion A (2004) Sensory aspects of consumer choices for meat and meat products. Meat Sci 66: 11-20.

14. Creed $P$ (1998) Sensory and nutritional aspects for sous vide processed foods In: Sous vide and cook-chill processing for the food industry, S Ghazala (Ed.), (pp. 57-88). Gaithersburg, MD: Aspen.

15. Castillo C (2007) Hidrólisis enzimática de Proteínas de músculo de salmón Cinética y Mecanismos. Bachelor Project, Departamento de Ingeniería Química y Ambiental, Universidad Técnica Federico Santa María.

16. Kristinsson H, Rasco BA (2000) Kinetics of the hydrolysis of Atlantic salmon
(Salmo Salar) muscle proteins by alkaline proteases and a visceral serine protease misxture. Process Biochem 36: 131-139.

17. Kristinsson HG, Rassco BA (2000) Biochemical and functional properties of Atlantic salmon (Salmo Salar) muscle proteins hydrolyzed with various alkaline proteases. J Agric Food Chem 48: 657-666.

18. Nielsen PM, Petersen D, Dambmann C (2001) Improved Method for Determining Food Protein Degree of Hydrolysis. J Food Sci 66: 642-646.

19. Szerman N, Gonzalez CB, Sancho AM, Grigioni G, Carduza F, et al. (2007) Effect of whey protein concentrate and sodium chloride addition plus tumbling procedures on technological parameters, physical properties and visual appearance of Sous Vide cooked beef. Meat Sci 76: 463-473.

20. Almonacid S, Bustamante J, Simpson R, Urtubia A, Pinto M, et al. (2012 Commercially sterilized mussel meats (Mytilus cholensis): a study on process yield. J Food Sci 77: R127-R135.

21. Nyati $H$ (2000) An evaluation of the effect of storage and processing temperatures on the microbiological status of sous vide extended shelf-life products. Food control 11: 471-476.

22. Szczesniak AS (2002) Texture is a sensory property. Food Qual Prefer 13 215-225. 